\title{
Factors Affecting the Implementation of Environmental Accounting by Construction Companies Listed on the Ho Chi Minh Stock Exchange
}

\author{
Thi Mai Huong NGUYEN 1 , Thi Kim Tuyen NGUYEN ${ }^{2}$, Thi Thao Vi NGUYEN ${ }^{3}$
}

Received: May 29, 2020 Revised: June 14, 2020 Accepted: July 03, 2020

\begin{abstract}
The study investigates Environmental Accounting Information(EAI) as well as factors affecting the environmental accounting implementation by the construction firms listed on the Ho Chi Minh Stock Exchange (HOSE), Vietnam. After eliminating seven enterprises that lacked data, the authors selected a sample of 112 observations from 28 construction businesses listed on the Ho Chi Minh Stock Exchange in the period 2015-2018. This study uses research data extracted from the companies' annual reports. Then, the data are analyzed by Stata 13 software, including descriptive statistics, correlation coefficient analysis, regression analysis of table data using estimation methods (Pooled OLS, REM, FEM), and testing of model defects (heteroskedasticity test, multicollinearity test, autocorrelation test). The results show that construction companies listed on the Ho Chi Minh Stock Exchange have out factors affecting the environmental accounting implementation by these enterprises, including independent audit firm and listed time. While the independent auditor firm has a positive and significant impact, the listed time has a negative influence. In addition, our study has confirmed the role of institutional factors affecting the disclosure level of EAI on the implementation of environmental accounting by construction enterprises listed on the Ho Chi Minh Stock Exchange.
\end{abstract}

Keywords: Environmental Accounting, Environmental Information, Environmental disclosure, Ho Chi Minh Stock Exchange, Vietnamese Construction Companies

JEL Classification Code: D22, G30, M41, O13, Q56

\section{Introduction}

Environmental accounting is often a component of social responsibility accounting. The environmental aspect of corporate social responsibility refers to the extent of business impact on the environment, encouraging firms to engage in environmentally-friendly activities. If environmental risks occur, companies are likely to have an imbalance between revenue and expenditure because of the increase in pollution

${ }^{1}$ First Author and Corresponding Author. Lecturer. Faculty of Accounting, Banking University of Ho Chi Minh City, Vietnam [Postal Address: 56 Hoang Dieu 2, Linh Chieu, Thu Duc, Ho Chi Minh City, 700000, Vietnam] Email: huongntm@buh.edu.vn

${ }^{2}$ Lecturer. Faculty of Economics and Accounting, Quy Nhon University, Vietnam. Email: nguyenthikimtuyen@qnu.edu.vn ${ }^{3}$ Faculty of Accounting, Banking University of Ho Chi Minh City, Vietnam. Email: thaovinguyen13@gmail.com

(c) Copyright: The Author(s)

This is an Open Access article distributed under the terms of the Creative Commons Attribution Non-Commercial License (http://Creativecommons.org/licenses/by-nc/4.0/) which permits unrestricted noncommercial use, distribution, and reproduction in any medium, provided the original work is properly cited. treatment costs, fines, compensation costs, etc. Nowadays, in developed countries, it is common that organizations disclose EAI, which “is used as input to a firm's decisionmaking" (Boyd, 1998). Moreover, the disclosure of EAI can become an indispensable element in implementing national sustainable development policies in the future.

Vietnam is not only a party of many free trade agreements, but also in the process of global economic integration. Vietnam has enacted policies on green growth, sustainable development, environmental protection, and environmental information disclosure. The Prime Minister issued Decision No. 1393/QD-TTg on "approving national strategy on green growth". By August 2018, the Prime Minister also promulgated Decision No. 950/QD-TTg on approving scheme for sustainable smart city development in the period 2018-2025 with a vision to 2030 to exploit and promote the potentials, improve resource utilization efficiency, and achieve the goal of sustainable smart urban development in Vietnam towards green growth. Besides, the Ministry of Construction also issued Decision No. 1659/QD-BXD 
on "promoting the action plan of the construction industry by implementing the national action plan to implement the 2030 agenda for sustainable development" and Circular No. 02/2018/TT-BXD on "providing for environmental protection in construction and reporting thereof". Due to the specific characteristics of the construction industry, construction activities can produce waste that has a significant impact on the environment as well as the quality of life of the people at different construction stages, from the pre-construction stage to the construction stage and post-construction stage, such as construction solid waste, construction materials waste, dust and toxic emissions of construction activities, etc. Therefore, the disclosure of EAI can be considered as an essential condition to enhance competitiveness and sustainable development of construction industry in related supply chains, such as manufacturing of building materials, interior and exterior equipment, construction design, real estate investment, financial services, banking, insurance, transportation, etc.

Besides, the Ministry of Finance also issued Circular No. 155/2015/TT-BTC guiding companies to disclose information on the stock market, effective from January 1, 2016. This Circular requires public companies to report on environmental and social responsibilities for the sake of sustainable development. Accordingly, companies are required to present information related to "Water", "Energy" and "Materials" in accordance with the requirements set out in this Circular for companies listed on the stock exchange (Figure 1). Most companies publish information related to environmental liabilities such as natural resource consumption tax and environmental protection tax, which shows that businesses tend to respond to government concerns about environmental issues.

In addition, accrued expenses such as accrued environmental costs are also found in companies' annual reports. Regarding environmental income, businesses mainly disclose the revenue from scrap sales. Turning to environmental costs, only Construction Investment Corporation 3-2 (C32) published this information from 2015 through 2018, which is the cost of quarry restoration. This company is also the one who disclosed environmental assets in 2015, which is an environmental protection deposit. These actions demonstrate that the government has been making a significant effort to protect the environment, which is conducive to Vietnam's sustainable development. Besides, assistance given by companies is required; they need to invest in environmental assets or environmental costs, such as costs of waste treatment, waste and emission control costs, etc. Because a lot of EAI arise, enterprises need to provide clear and transparent information to stakeholders because accounting information in general, and EAI in particular, has a strong impact on the behavior of market participants. Therefore, this paper is conducted to help construction firms realize the importance of disclosing EAI, which contributes to promoting businesses to publish more EAI in the future.

Therefore, this paper is conducted to assess EAI disclosure and measure the factors affecting the environmental accounting implementation of construction enterprises listed

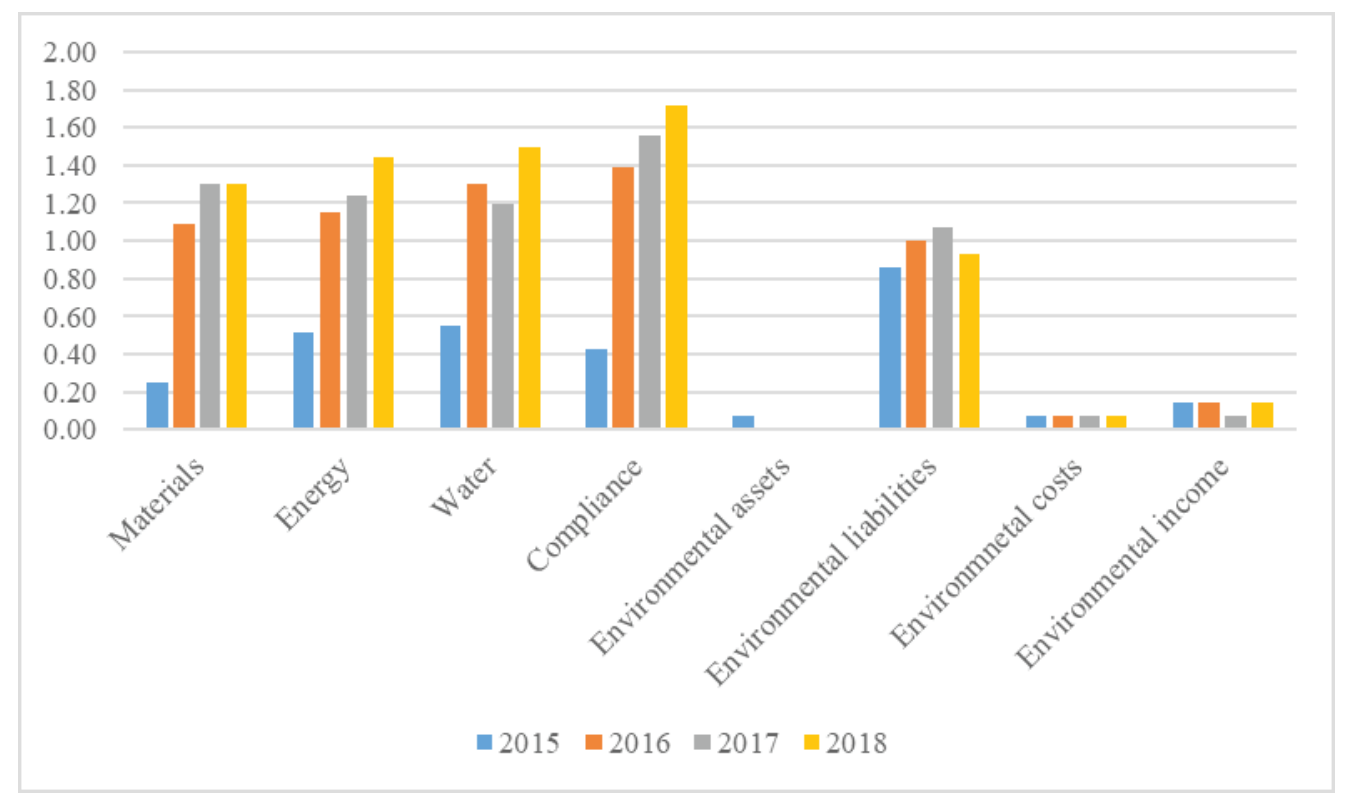

Source: Results calculated by authors

Figure 1: The disclosure level of environmental accounting information at Vietnam in the period $2015-2018$. 
on the Ho Chi Minh City Stock Exchange (HOSE). This helps state agencies to promote construction firms to publish more EAI in the future.

This paper consists of six sections. The rest of the paper is organized as follows. The second section presents the research overview, followed by the research method. Then, the authors present and discuss the research results. Finally, conclusions show the implications, limitations and future directions.

\section{Literature Review}

The definition of sustainable development was introduced in the 1970s, with the development of this concept, environmental accounting has developed into a new branch of accounting science (Yakhou \& Dorweiler, 2004) and is considered as a tool to reflect and protect economic activities related to the environment. "The Greening of Accountancy: The Profession after Pearce" published by Gray in 1990 is widely acknowledged as a breakthrough in environmental accounting research, and this subject has received a great deal of attention in the global academic world. According to Gray (1990), environmental accounting is "accounting about increase or decrease on artificial assets and natural assets, most importantly accounting of conversion between the two assets". Accordingly, there have been quite a few studies addressing this issue, such as the research by Gray and Bebbington (2001) showing that environmental accounting is not only restricted to corporate accounting. Hines (1988), Peskin and Angeles (2001) argue that environmental accounting is considered a tool for measuring economic performance, such as GDP, NDP, GNP, or NNP. According to Steele and Powell (2002), environmental accounting is defined as the identification, allocation, and analysis of material and related cash flows by using environmental accounting management systems. Solomon and Thomson (2009) argued that environmental accounting should have certain attributes including empiricalness, systematicity, transparency, objectivity, reliability, comprehensiveness, verification, suitability, and equity to gather natural, economic, cultural, ethical and social resources to achieve the environmental and social efficiency of various entities.

From the perspective of information disclosure, environmental accounting is researched by many scholars around the world to explain environmental disclosure behavior of firms. Jones (2010) investigated factors affecting the disclosure level of environmental accounting. The result showed that there was a considerable impact between industry and the environment. Besides, to assess the impact of industry, a measurement system is needed, but the current accounting system cannot perform this function due to various reasons such as monetary dependence, business concentration, capitalist orientation, etc. Therefore, in order to capture the company's environmental impacts, a new accounting system is required because the traditional accounting model only focuses on accounting data but does not capture the impact on the environment. Hence, companies should report EAI in their annual reports to stakeholders. Jamil, Mohamed, Muhammad and Ali (2015) researched the barriers and factors affecting the practice of environmental management accounting for small and medium-sized manufacturing companies in Malaysia. The author collected data through questionnaires and applying institutional theory. The results showed that companies' budgets were allocated for environmental activities and environmental management accounting practices. It is argued that the dominant factor in the practice of environmental accounting is coercion; therefore, the Malaysian government and other authorities need to address barriers to the development of environmental management accounting.

Wachira (2014) investigated environmental accounting practices for 30 enterprises in different fields in Nairobi, Kenya. The study was based on legislative theory, institutional theory and management theory to determine the relationship with factors: firm size, firm age, technology, compliance costs, financial operations and environmental strategy. The findings showed that there was a weak correlation between technology and the adoption of environmental management accounting practices. The results also showed that compliance cost, environmental strategy and financial performance had a significant effect on the adoption of environmental management accounting practices. Firm size and firm age are two factors that do not have any association with the level of environmental management accounting practice. In addition, it was found that hierarchical culture and defensive strategies are factors that hinder businesses from practicing environmental management accounting. Barakat, Perez and Ariza (2015) also conducted a study to evaluate the level of corporate social responsibility disclosure in Palestine and Jordan.

In all respects, the disclosure level of EAI in Jordan is higher than in Palestine; however, the disclosure level of EAI in both countries is low compared to western countries. This proves that businesses in Jordan are more concerned about resources and community commitments. The results showed that the legal system, audit firms, corporate governance, board size and auditing committees have a positive influence on corporate social responsibility disclosure. Governance committees and the percentage of independent directors on the board have no influence on corporate social responsibility disclosure. In addition, the study also showed that the firm size and profitability have a positive association with the level of corporate social responsibility disclosure, while firm age and industry have a reverse relationship with corporate social responsibility disclosure. 
Hasan and Hosain (2015) also conducted research on factors affecting the mandatory and voluntary disclosure level of environmental and social information of businesses listed on the Dhaka Stock Exchange in Bangladesh. Using the regression analysis method, the study was conducted on a sample of 54 listed enterprises in the period 2010-2013. There are four factors used in the study, including firm size, firm age, profitability and industry type. The results showed that enterprises that disclosed voluntary information aboveaverage accounted for $71 \%$. The study also found that firm size in terms of total assets and industry type had a positive impact on the disclosure level of voluntary information. On the contrary, profitability and firm age do not affect the disclosure level of voluntary information. The compliance level of disclosure requirements is poor among companies. Most enterprises published mandatory information with an average of about $50.62 \%$ in the period of $2010-2013$, the lowest was $20.89 \%$ and the highest was $77.08 \%$. The results also indicated that the key determinants of mandatory information disclosure are firm age and industry type. Meanwhile, firm size in terms of assets and revenue and profitability have no relationship to the disclosure level of mandatory information.

Yang and Liang (2017) conducted a study on the factors affecting the disclosure level of environmental accounting information for listed companies of paper printing and printing industry in the period 2013-2015. Using inductive analysis methods combined with empirical analysis, the paper was conducted on a sample of 32 listed companies collected on the Shenzhen Stock Exchange, the Shanghai Stock Exchange and China's Wind database. The study used the EAI disclosure index to measure the disclosure level of EAI of listed companies in the printing industry. This research builds a research model based on six impact factors including the proportion of tradable shares, company size, the extent of liabilities, profitability, growth ability and whether through the ISO14001 certification. The results indicated that company size and whether through the ISO14001 certification had a positive influence on the disclosure level of EAI.

In Vietnam, Nguyen, Tran, Nguyen and Le (2017) analyzed the factors affecting the disclosure level of EAI of 71 listed companies on the Vietnam Stock Exchange between 2013 and 2016. The results showed that firm size, profitability, listed time and independent audit were positively associated with the disclosure level of EAI. Meanwhile, financial leverage gives opposite result. The results also indicated that the disclosure level of EAI of construction companies was on an upward trend, especially in 2016. In the next year, Nguyen, Tran and Nguyen (2018) evaluated the factors affecting the disclosure level of EAI of 85 listed enterprises operating in a parent-subsidiary business model on the Vietnam Stock Exchange in the period 2013-2017.
The findings showed that business size, foreign ownership, profitability, leverage, listed time and independent auditing were significantly associated with the disclosure level of EAI.

Using FEM, REM estimation method, Nguyen, Le, and Pham (2018) also pointed out that firm size and listed time have a positive impact on the disclosure level of EAI for food processing enterprises listed on Ho Chi Minh Stock Exchange. Lam (2019) evaluated factors affecting the disclosure of EAI in Vietnamese seafood enterprises. The findings showed that six factors affecting environmental accounting information disclosure in descending order as follows: (i) supervision of management agencies for environmental protection measures at enterprises, (ii) environmental accounting proficiency of accountants, (iii) attitudes of managers about environmental protection, (iv) guidelines for performing environmental accounting, (v) pressure from governments, importers, investors, financial institutions, communities on environmental information, and (vi) benefits of performing environmental accounting. Using data of 106 listed firms on the Vietnam stock market from three industries (forestry and fisheries, industry and construction, trade and services), Nguyen, Nguyen, Nguyen, Le, and Nguyen (2020) point out that EAI disclosure depends heavily on government regulations, then stakeholders pressure, view of company managers, firms size, community pressure, enterprises sector, profitability. Except for profits, the remaining variables positively impact on the disclosure of EAI.

In the same year, Nguyen (2020) studies environmental accounting implementation in mining industry in Binh Dinh province in Vietnam through Cronbach's alpha analysis, exploratory factor analysis and multivariate regression analysis. The results prove different factors impact on environmental accounting implementation in this industry in Binh Dinh province, including: stakeholder pressure, corporate characteristics, coercive pressure of government agencies, environmental awareness of senior managers and accountant qualifications of environmental accounting. All factors in research model of Nguyen (2020) have positive effect on environmental accounting implementation in mining enterprises in Binh Dinh province in Vietnam.

\section{Methodology}

\subsection{Hypotheses Development}

\subsubsection{Firm Size}

According to Institutional theory, large companies face more legal issues and have more social expectation than small ones (Firth, 1979). Therefore, big firms disclose more EAI. Some previous studies have also found a positive association between firm size and the disclosure level of 
EAI (Liu \& Anbumozhi, 2009; Megbuluba, 2017; Nguyen, Tran \& Nguyen, 2018). Therefore, the first hypothesis is formulated:

H1: The larger the firm size is, the higher the disclosure level of environmental accounting information is

\subsubsection{Profitability}

Stakeholder theory indicates that the more profitable companies are, the more they are willing to meet the needs of their stakeholders by disclosing more information. Besides, as companies operate effectively, they often ensure sufficient financial resources for information disclosure. In particular, companies doing business with foreign enterprises should publish more EAI to increase competitiveness as well as improve reputation since EAI has significant effect on the business profitability. The results of some previous studies showed that profitability has significant positive effect on the disclosure level of EAI (Arif \& Tuhin, 2013; Lu \& Abeysekera, 2014; Nguyen, Tran \& Nguyen, 2018). Therefore, the second hypothesis is formulated:

H2: The higher the profitability of a company is, the higher the disclosure level of environmental accounting information is

\subsubsection{Leverage}

Theory of stakeholders shows a high degree of leverage leads to increase conflict of interest among stakeholders. Hence, companies tend to disclose more EAI to meet stakeholders' requirements, which also helps to maintain strong relationships with stakeholders and financial stability for business. High financial leverage, however, still brings many potential risks. The financial capacity of the enterprise will be affected; the enterprise may not be able to cope with debts and the unbalance of solvency. It is clear that the benefits of stakeholders will be greatly affected. This makes it more difficult for businesses to decide to spend on environmental issues. Chiu and Wang (2015) found that there is a negative relationship between leverage and the EAI's disclosure level. Therefore, the third hypothesis is set up:

H3: The higher the financial leverage is, the lower the disclosure level of environmental accounting information is

\subsubsection{Independent Audit Firm}

According to Legitimacy theory, stakeholders play a vital role in maintaining business operations because they provide the necessary resources to ensure the survival of firms, and the environmental information that the businesses reveal also influences the decision-making of stakeholders on their operations. Thus, companies have responsibility to publish EAI for stakeholders. With the requirement of disclosing environmental information mentioned in Circular 155/2015/TT-BTC, auditing companies having reputable and professional capacity on environmental accounting will have support to evaluate, consult and complete this content in Vietnamese construction enterprises. Thus, enterprises actively choose the Big 4 audit firms and it is considered a good sign to improve information transparency. Therefore, the fourth hypothesis is formulated:

H4: The more reliable the independent audit firm is, the higher the disclosure level of environmental accounting information is

\subsubsection{Listed Time}

According to Legitimacy theory, longer-listed companies are more likely to comply with the disclosure requirements due to their experience and desire to maintain their image and reputation. Galani, Alexandridis and Stavropoulos (2011), enterprises with long-listed time have more advantages in improving the practical conditions to support information disclosure, improve technology and meet the costs for information disclosure. However, prior research has provided mixed results about the relationship between the listed time and the disclosure level of EAI. Some studies such as Wachira (2014) and Barakat, Perez and Ariza (2015) reported that no association has been found between firm age and the disclosure level of EAI. Nevertheless, the research by Nguyen, Tran, Nguyen and Le (2017) shows that the listed time has positive influence on the disclosure level of EAI. Based on the similarity of industry and the scope of research between this paper and the research of Nguyen, Tran, Nguyen and Le (2017), the authors predict the fifth hypothesis as follow:

H5: The higher the listed time is, the higher the disclosure level of environmental accounting information is

\subsection{Model Construction}

The regression model has the following form:

$$
\begin{aligned}
& \mathrm{EAID}=\beta_{0}+\beta_{1} \mathrm{SIZE}+\beta_{2} \mathrm{PRO}+\beta_{3} \mathrm{LEV}+\beta_{4} \mathrm{AUD} \\
& +\beta_{5} \mathrm{AGE}+\mathcal{E} \\
& \text { where } \\
& \text { EAID: the disclosure of EAI } \\
& \beta_{0} \text { : Constant } \\
& \beta_{1}, \beta_{2}, \beta_{3}, \beta_{4}, \beta_{5} \text { : Regression coefficients }
\end{aligned}
$$


PRO: Profitability

LEV: Leverage

AUD: Independent audit firm

AGE: Listed time

E: Random error term

\subsection{Variables Measurement}

\subsubsection{Measurement of the Dependent Variable}

In this paper, we have inherited the measurement method developed in the research by Nguyen, Tran, Nguyen, and Le (2017). Accordingly, we will also use a weighted disclosure index to measure the disclosure of EAI, meaning that each item will be scored based on the quality of the information being disclosed. The scores for evaluating disclosed items will range from 0 to 4 . In particular, 4 is for both qualitative and quantitative information; 3 is for qualitative information only, no quantitative information; 2 is for quantitative information both in terms of objects and values, no qualitative information; 1 is for quantitative information about values, no objects and no qualitative information; and 0 is for no published information.

On the basis of the method of scoring the above items, the EAI disclosure index of each enterprise is calculated by the following formula:

$$
Y=\frac{\sum_{i=1}^{n} X i}{n}
$$

Table 1: Description of independent variables where

Y: EAI disclosure index

$\mathrm{Xi}$ : The score of the information item i published by the company

$\mathrm{n}$ : Number of items $(\mathrm{n}=9)$

\subsubsection{Measurement of the Independent Variables}

The method of measuring five independent variables is shown in Table 1 below:

\subsection{Research Sample}

This study uses secondary data sets collected from the reports of construction enterprises listed on the HOSE. To collect data on the EAI index, we used the annual reports published on the company's official website or via the website VietstockFinance for the period 2015-2018. We generated a panel dataset, which combines observations in time series and spatial series. According to data published in the annual report of HOSE, by the end of 2018, there were 35 construction firms listed on HOSE. We excluded seven listed companies because they have missing data for four consecutive years from 2015 to 2018 . Thus, the data used in this paper includes 112 observations of 28 construction enterprises over the period 2015-2018.

\subsection{Research Methods}

After collecting panel data as above, we imported the processed data into Stata 13.0 for data analysis. First,

\begin{tabular}{|c|c|c|c|c|}
\hline Variable name & $\begin{array}{c}\text { Variable } \\
\text { code }\end{array}$ & Measurement & Source & $\begin{array}{c}\text { Expected } \\
\text { signs }\end{array}$ \\
\hline Firm size & SIZE & Log of total assets & $\begin{array}{l}\text { Liu \& Anbumozhi (2009); Wachira (2014); } \\
\text { Chaklader \& Gulati (2015); Barakat, Perez \& } \\
\text { Ariza (2015); Hasan \& Hosain (2015), Yang \& } \\
\text { Liang (2017); Nguyen, Tran, \& Nguyen (2018) }\end{array}$ & $(+)$ \\
\hline Profitability & PRO & Profit after tax / Equity & $\begin{array}{c}\text { Barakat, Perez, \& Ariza (2015); Hasan \& } \\
\text { Hosain (2015), Yang \& Liang (2017); Nguyen, } \\
\text { Tran, \& Nguyen (2018) }\end{array}$ & $(+)$ \\
\hline Leverage & LEV & Total debt / Total assets & $\begin{array}{c}\text { Chaklader \& Gulati (2015); Chiu \& Wang } \\
\text { (2015); Nguyen, Tran, Nguyen, \& Le (2017); } \\
\text { Nguyen, Tran, \& Nguyen (2018) }\end{array}$ & $(-)$ \\
\hline $\begin{array}{l}\text { Independent } \\
\text { audit firm }\end{array}$ & AUD & $\begin{array}{l}\text { Dummy variable } \\
\text { 0: The Non Big } 4 \text { Accounting } \\
\text { Firms } \\
\text { 1: The Big } 4 \text { Accounting Firms }\end{array}$ & $\begin{array}{c}\text { Barakat, Perez, \& Ariza (2015); Nguyen, Tran, } \\
\text { Nguyen, \& Le (2017); Nguyen, Tran, \& Nguyen } \\
\text { (2018) }\end{array}$ & $(+)$ \\
\hline Listed time & AGE & $\begin{array}{c}\text { Number of years from the } \\
\text { beginning of listing to the end } \\
\text { of } 2018\end{array}$ & $\begin{array}{l}\text { Liu \& Anbumozhi (2009), Nguyen, Tran, } \\
\text { Nguyen, \& Le (2017); Nguyen, Tran, \& Nguyen } \\
\text { (2018); Nguyen, Le, \& Pham (2018) }\end{array}$ & $(+)$ \\
\hline
\end{tabular}


descriptive statistics are used to summarize our sample data. Second, we conducted a correlation analysis to determine the relationship among variables in the research model. Next, Pooled OLS, Fixed Effects Model (FEM) and Random Effects Model (REM) regression models were employed to analyze the data. The Hausman test is used in this paper to help select the appropriate model between FEM and REM. If the FEM is selected, the selection process will end. If the REM is selected, the selection process should be continued by using the Lagrange factor test, also known as BreuschPagan Lagrange, to select REM or Pooled OLS. The final step is to test for heteroskedasticity, autocorrelation and multicollinearity. In particular, multicollinearity test is used to determine whether the independent variables in the model are linearly related to each other. The autocorrelation test is used to examine whether or not the errors are correlated with each other. The heteroskedasticity test is used to check whether the residuals in the regression model have the same variance.

\section{Results}

\subsection{Descriptive Statistics}

Descriptive statistical results of 112 observations show that the disclosure level of EAI of listed construction companies is at a relative level. Table 2 provides descriptive statistics for the independent variables and the dependent variables. The results show that the mean value of the dependent variable is 1.117 , with a minimum value of 0 and a maximum of 3.111 . The minimum value showed that some companies do not disclose EAI in their annual reports. However, most of these figures were recorded in 2015, which is the first year that businesses publish EAI according to Circular 155/2015/TT-BTC. Therefore, many businesses are not familiar with the new regulations, which leads to difficulties in disclosing EAI. Despite many challenges in the first year, the results show that businesses disclose more information in subsequent years during the research period.

Regarding independent variables, there are some noticeable features as follows:
Firm size ranges widely from 11.371 to 13.226 , corresponding to the total assets of VND234,698,939,055 to VND16,823,061,946,342. In particular, the smallest scale belongs to the HACISCO Joint Stock Company (HAS) in 2018 with total assets of VND234,698,939,055. The largest scale belongs to one of the leading enterprises of the construction industry, which is COTECCONS Construction Joint Stock Company, with total assets of VND16,823,061,946,342. The enterprises in the sample are all large-scale enterprises with a total capital of more than VND100 billion.

The profitability of construction businesses ranges from $-82.2 \%$ to $58.2 \%$, with an average of $12.9 \%$. This means that there is a big difference in business performance among businesses.

The leverage of construction companies varies from $15 \%$ to $88.6 \%$, with an average of $65.5 \%$. This average leverage ratio is in line with the investment characteristics of the construction industry as this industry often requires a large investment in construction.

The role of the independent audit firm reaches an average of 0.259 . The majority of businesses choosing the Big 4 accounting firms have total assets from VND1,000 billion to VND5,000 billion. Those are companies whose stock symbols are CTD, DIG, HBC, L10, LCG, LM8, and PXI. They not only disclose information on materials, energy, water, compliance as required in Circular 155/2015/ TT-BTC, but also disclose more other information such as emissions, effluents and waste, etc. Meanwhile, the remaining businesses all choose the non-Big 4 accounting firms.

The standard deviation of the listed time is 3.436 ; the longest listed time among construction businesses is 17 years, and the average listed time is more than 8 years. This proves that the experience gap of listed companies is quite large (see Table 2).

\subsection{Correlation Analysis}

Table 3 shows the results of correlation analysis among variables in research model. Based on the analysis results, the variables on the model have low statistical significance.

Table 2: Statistical Analysis

\begin{tabular}{|l|c|c|c|c|c|}
\hline \multicolumn{1}{|c|}{ Variable } & Obs & Mean & Std.Dev. & Min & Max \\
\hline EAID & 112 & 1.117 & 1.082 & 0 & 3.111 \\
\hline SIZE & 112 & 12.245 & 0.447 & 11.371 & 13.226 \\
\hline PRO & 112 & 0.129 & 0.179 & -0.822 & 0.582 \\
\hline LEV & 112 & 0.655 & 0.165 & 0.150 & 0.886 \\
\hline AUD & 112 & 0.259 & 0.440 & 0 & 1 \\
\hline AGE & 112 & 8.714 & 3.436 & 1 & 17 \\
\hline
\end{tabular}


Table 3: Correlation analysis

\begin{tabular}{|c|c|c|c|c|c|c|}
\hline & EAID & SIZE & PRO & LEV & AUD & AGE \\
\hline EAID & 1 & & & & & \\
\hline SIZE & $\begin{array}{l}0.0522 \\
0.5847\end{array}$ & 1 & & & & \\
\hline PRO & $\begin{array}{l}0.0545 \\
0.5684\end{array}$ & $\begin{array}{l}0.2766 \\
0.0032\end{array}$ & 1 & & & \\
\hline LEV & $\begin{array}{l}0.0753 \\
0.4298\end{array}$ & $\begin{array}{l}0.2670 \\
0.0044\end{array}$ & $\begin{array}{c}-0.0737 \\
0.4398\end{array}$ & 1 & & \\
\hline AUD & $\begin{array}{l}0.1207 \\
0.2047\end{array}$ & $\begin{array}{l}0.5136 \\
0.0000\end{array}$ & $\begin{array}{l}0.0227 \\
0.8123\end{array}$ & $\begin{array}{l}0.1267 \\
0.1832\end{array}$ & 1 & \\
\hline AGE & $\begin{array}{c}-0.1702 \\
0.0728\end{array}$ & $\begin{array}{c}-0.0393 \\
0.6807\end{array}$ & $\begin{array}{c}-0.3581 \\
0.0001\end{array}$ & $\begin{array}{l}0.0679 \\
0.4770\end{array}$ & $\begin{array}{l}0.2936 \\
0.0017\end{array}$ & 1 \\
\hline
\end{tabular}

Table 4: Regression results and the Hausman test

\begin{tabular}{|c|c|c|c|c|c|c|c|c|}
\hline & Coefficients & SIZE & PRO & LEV & AUD & AGE & R-Squared & Hausman test \\
\hline OLS & 2.550 & $\begin{array}{l}-0.044 \\
(0.918)\end{array}$ & $\begin{array}{l}-0.857 \\
(0.183)\end{array}$ & $\begin{array}{l}-0.173 \\
(0.856)\end{array}$ & $\begin{array}{c}1.037 \\
(0.004)\end{array}$ & $\begin{array}{l}-0.108 \\
(0.053)\end{array}$ & 0.1626 & \\
\hline FEM & -16.035 & $\begin{array}{c}1.524 \\
(0.068)\end{array}$ & $\begin{array}{l}-1.353 \\
(0.060)\end{array}$ & $\begin{array}{l}-2.680 \\
(0.097)\end{array}$ & $\begin{array}{c}1.626 \\
(0.001)\end{array}$ & $\begin{array}{c}0 \\
\text { Omitted }\end{array}$ & 0.2052 & \multirow{2}{*}{$\begin{array}{c}\text { Prob }>\text { chi } 2= \\
0.0289\end{array}$} \\
\hline REM & 2.550 & $\begin{array}{l}-0.044 \\
(0.918)\end{array}$ & $\begin{array}{l}-0.857 \\
(0.183)\end{array}$ & $\begin{array}{l}-0.173 \\
(0.856)\end{array}$ & $\begin{array}{c}1.037 \\
(0.004)\end{array}$ & $\begin{array}{l}-0.108 \\
(0.053)\end{array}$ & 0.1626 & \\
\hline
\end{tabular}

The correlation coefficient between the independent variables and the dependent variable is in the range of 0.0522 to 0.1702 , and the independent variables have a low correlation with the dependent variables. Firm size (SIZE), profitability (PRO) and independent audit firm (AUD) have a positive relationship with the disclosure level of EAI. This finding is consistent with previous studies and the authors' expectations. However, leverage (LEV) and listed time (AGE) have the opposite results. The correlation coefficient among the independent variables varies from 0.0227 to 0.5136 , and these coefficients are all less than 0.8 . Therefore, it can be concluded that the multi-collinear phenomenon does not occur in the model.

\subsection{Testing the Suitability of the Model}

We employ the Pooled OLS model, fixed effect model (FEM) and random impact model (REM) to analyze the data. Table 4 reports the results of the regression using these three models. To select FEM and REM, we continue to use the Hausman test. We test the null hypothesis that the REM is appropriate. The results show that Prob $>$ chi $2=0.0289<$ $5 \%$, which means that the null hypothesis is rejected. Thus, the model selection process is finished, and the appropriate model for this study is the fixed effect model (FEM).

\subsection{Regression Assumption Test Results}

In the beginning, the authors use the Wald test to detect heteroscedasticity. The objective is to test the null hypothesis that there is no heteroskedasticity in the model. The results show that Prob $>$ chi $2=0.0000<5 \%$, meaning that we reject the null hypothesis. Hence, heteroskedasticity is present in the model. Besides, Wooldridge test is used to check on the presence of autocorrelation. We aim to test the null hypothesis that the autocorrelation does not exist in the model. The findings indicate that Prob $>\mathrm{F}=0.0000<5 \%$, which allows us to reject the null hypothesis and confirms the existence of autocorrelation. We also use the Collin test to test for multicollinearity. The results show that VIF value is all less than 10. Thus, it can be concluded that there is no multicollinearity in the research model.

\subsection{Regression Results}

According to Wooldridge (2002), in order to address the problem of heteroskedasticity and autocorrelation, the Feasible Generalized Least Squares (FGLS) model should be used to ensure stability and effectiveness of estimation. Beck and Katz (1995), Hoechle (2007) also pointed out that the FGLS model is a suitable choice when the model violates 
the two above problems. Therefore, the authors conducted regression by this estimation method. The results of testing the relationship between dependent variables and independent variables through FGLS model are presented in Table 5.

As shown in Table 5, listed time (AGE) and independent audit firm (AUD) have an impact on the disclosure level of EAI at the significant level of $5 \%$, with $\mathrm{P}>|\mathrm{z}|$ respectively of 0.000 and 0.002. In particular, AUD has a positive relationship $(\beta>0)$ with the disclosure level of EAI, while AGE has a negative impact $(\beta<0)$ on the disclosure level of EAI. Moreover, AUD also has the strongest impact $(|\beta|=$ $0.857)$ on the disclosure level of EAI compared to AGE $(|\beta|$ $=0.075)$. The remaining variables such as firm size (SIZE), profitability (PRO), and leverage (LEV) have low statistical significance in the model. So, the official regression equation is as follows:

$$
\mathrm{EAID}=-0.415+0.857 \mathrm{AUD}-0.075 \mathrm{AGE}+\mathcal{E}
$$

\section{Discussion}

From the above research results, the independent audit firm (AUD) has positive impact on the disclosure level of EAI of construction companies listed on the Ho Chi Minh Stock Exchange. This means that the more reliable the independent audit firm is, the higher the disclosure level of EAI is. The above findings show that published information is compliant with Circular 155/2015/TT-BTC. According to Saifullah, Kari and Ali (2017) also present is the fact that government policy has a direct impact on public environment awareness. Moreover, when having independent auditing firms, EAI disclosure is more qualitative and standardized. This makes stakeholders more satisfied because of the high reliability of environmental information. This result is compatible with the authors' expectation, and the hypothesis $\mathrm{H}_{5}$ is supported. This result is also consistent with the results of previous studies such as Barakat, Perez and Ariza (2015); Nguyen, Tran, Nguyen and Le (2017); Nguyen, Tran and Nguyen (2018).

In contrast, listed time (AGE) has a negative relationship with the disclosure level of EAI of construction companies listed on the Ho Chi Minh Stock Exchange. This result is contrary to the author's expectation, and the hypothesis $\mathrm{H}_{4}$ is not supported. In addition, this finding is also different from the results of previous studies such as Liu and Anbumozhi (2009); Nguyen, Tran, Nguyen and Le (2017); Nguyen, Tran and Nguyen (2018); Nguyen, Le, and Pham (2018). As mentioned earlier, companies with longer listed times have more advantages in disclosing information because they have a well-established disclosure process. However, the disclosure or non-disclosure is no longer voluntary as before, but rather as a binding legal regulation of Circular 155/2015/TT-BTC, which means that newly-listed or longlisted businesses must report EAI in their annual reports. Furthermore, it is not excluded that the disclosure of EAI by long-listed companies is currently following a rut. Based on the above arguments, it can be concluded that long-listed firms have a lower disclosure level of EAI than newly listed businesses.

The results also found that firm size (SIZE) and profitability (PRO) are positively and insignificantly affect on the disclosure level of EAI, while leverage (LEV) is negatively and insignificantly affect. In terms of measurement, these three variables are all measured from financial ratios. Echave and Bhati (2010) concluded that no association had been found between the disclosure level of corporate social and environmental information and financial variables. Similarly, Wijewardana (2017) also suggests that financial variables insignificantly affect the disclosure level of EAI. Therefore, the results in this paper are appropriate. All of the above arguments are the reason why financial variables have low statistical significance. Besides, comparing this research with that of Nguyen, Tran, Nguyen and Le (2017), both studies are conducted on construction companies in Vietnam. However, if the results of the research of Nguyen, Tran, Nguyen and Le (2017) had shown that the disclosure of EAI is voluntary, the results of our study would have confirmed the role of institutional factor affecting the disclosure level of EAI, which is clearly shown when the secondary data used in our study is related to the validity and compliance of listed companies under Circular 155/2015/TT-BTC.

Table 5: FGLS Regression Results

\begin{tabular}{|l|c|c|c|c|}
\hline EAID & Coefficients & Standard Errors & $\mathbf{Z}$ & $\mathbf{P}>|\mathbf{z}|$ \\
\hline SIZE & 0.173 & 0.255 & 0.680 & 0.499 \\
\hline PRO & 0.069 & 0.436 & 0.160 & 0.874 \\
\hline LEV & -0.586 & 0.472 & -1.240 & 0.214 \\
\hline AUD & 0.857 & 0.271 & 3.160 & 0.002 \\
\hline AGE & -0.075 & 0.021 & -3.580 & 0.000 \\
\hline Constant & -0.415 & 2.987 & -0.140 & 0.890 \\
\hline
\end{tabular}




\section{Conclusion}

This study recognizes and measures the influence level of factors on EAI of construction enterprises listed on the Ho Chi Minh Stock Exchange. Based on 112 observed variables, the result shows different factors impact on EAI disclosure through descriptive statistics analysis, correlation analysis, and regression analysis of panel data. There are two factors that have a considerable effect. Independent auditing firm has positive and significant influence at $5 \%$ statistical significance, while the listed time has a negative impact at $1 \%$ statistical significance. On the other hand, the disclosure of EAI construction firms listed on the Ho Chi Minh Stock Exchange is not consistent because the government agencies have not promulgated standards and principles for recording EAI.

The information that business disclosure is generally more positive than negative, and the published EAI is mainly related to legal requirements that the State requires. Circular $155 / 2015 /$ TT-BTC is based on the guidance of GRI, but this Circular only refers to the criteria that need to be published. Therefore, the Vietnamese government agencies should quickly detail these criteria in Circular 155/2015/TT-BTC to develop the environmental accounting system in Vietnam and to match the international perspective. This ensures consistency and compatibility with international guiding documents, especially when Vietnam is following a roadmap for the application of IFRS in the coming time. Furthermore, companies are a key factor in the process of improving environmental accounting disclosure. The research results show that enterprises using the services of Big 4 audit firms have higher disclosure levels of EAI. This proves that the published EAI, not only satisfies the compliance aspect, but also is clear, specific, and even more detailed than Circular 155/2015/TT-BTC. Therefore, businesses need to consider using Big 4 audit services to increase the transparency of information and build trust with stakeholders. This also helps protect investors' legitimate rights and interests in the market in general and in the information disclosure of public companies in particular.

This study uses a small sample of the construction firms listed on the Ho Chi Minh Stock Exchange, Vietnam. However, research results provide a new perspective on EAI disclosure in an environmentally-sensitive industry in Vietnam. Although the authors know that enterprises use multiple information channels to disclose environmental information, this article only uses annual reports to collect research data. Therefore, future studies can expand into sustainability reports, social responsibility reports, etc. At the same time, other studies may verify new factors and new scales to EAI disclosure.

\section{References}

Arif, H. M., \& Tuhin, M. H. (2013). Disclosure of non-financial information voluntarily in the annual report of financial institutions: a study on listed banks of Bangladesh. European Journal of Business and Economics, 8(2), 37-42. https://doi. org/10.12955/ejbe.v8i2.397

Barakat, F. S., Pérez, M. V. L., \& Ariza, L. R. (2015). Corporate social responsibility disclosure (CSRD) determinants of listed companies in Palestine (PXE) and Jordan (ASE). Review of Managerial Science, 9(4), 681-702. https://doi.org/10.1007/ s11846-014-0133-9

Beck, N., \& Katz, J. N. (1995). What to do (and not to do) with time-series cross-section data. American Political Science Review, 89(3), 634-647. https://doi.org/10.2307/2082979

Boyd, J. W. (1998). The benefits of improved environmental accounting: an economic framework to identify priorities. Resources for the Future. Discussion Paper 98-49 [September] 1998, Washington, DC. Retrieved from http://www. rff. org./ Boyd. cfm.

Chaklader, B., \& Gulati, P. A. (2015). A study of corporate environmental disclosure practices of companies doing business in India. Global Business Review, 16(2), 321-335. https://doi.org/10.1177/0972150914564430

Chiu, T. K., \& Wang, Y. H. (2015). Determinants of social disclosure quality in Taiwan: An application of stakeholder theory. Journal of Business Ethics, 129(2), 379-398. https://doi. org/10.1007/s10551-014-2160-5

Echave, J. \& Bhati, S. S. (2010). Determinants of social and environmental disclosures by Spanish Companies. GSMI Third Annual International Business Conference (pp. 5568). Michigan, USA December 2-4. Michigan, USA: Global Strategic Management Inc.

Firth, M. (1979). The impact of size, stock market listing, and auditors on voluntary disclosure in corporate annual reports. Accounting and Business Research, 9(36), 273-280. https://doi.org/10.1080/00014788.1979.9729168

Galani, D., Alexandridis, A., \& Stavropoulos, A. (2011). The association between the firm characteristics and corporate mandatory disclosure the case of Greece. World Academy of Science, Engineering and Technology, 77, 101-107. http://doi. org/10.5281/zenodo. 1076164

Gray, R. (1990). The Greening of Accountancy: The Profession after Pearce. Retrieved from https://www.researchgate.net/ publication/329220785_The_Greening_of_Accountancy_ The_Profession_After_Pearce

Gray, R., \& Bebbington, J. (2001). Accounting for the Environment (2nd ed.). http://dx.doi.org/10.4135/9781446220849

Hasan, M. T., \& Hosain, M. Z. (2015). Corporate mandatory and voluntary disclosure practices in Bangladesh: Evidence from listed companies of Dhaka Stock Exchange. Research Journal of Finance and Accounting, 6(12), 14-32. 
Hines, R. D. (1988). Financial accounting: in communicating reality, we construct reality. Accounting, Organizations and Society, 13(3), 251-261. https://doi.org/10.1016/03613682(88)90003-7

Ho Chi Minh Stock Exchange (2018). 2018 Annual Report. Ho Chi Minh City, Vietnam: HOSE. Retrieved May 01, 2018, from https://www.hsx.vn/Areas/Desktop/Web/ AnnualReportView?fid=53b3300db569458d93ae9899e2c87d08

Hoechle, D. (2007). Robust standard errors for panel regressions with cross-sectional dependence. The Stata Journal, 7(3), 281312. https://doi.org/10.1177/1536867X0700700301

Jamil, C. Z. M., Mohamed, R., Muhammad, F. and Ali, A. (2015). Environmental Management Accounting Practices in Small Medium Manufacturing Firms. Procedia - Social and Behavioral Sciences, 172, 619-626. https://doi.org/10.1016/j. sbspro.2015.01.411

Jones, M. J. (2010). Accounting for the environment: Towards a theoretical perspective for environmental accounting and reporting. Accounting Forum, 34(2), 123-138. https://doi. org/10.1016/j.accfor.2010.03.001

Lam, T. T. L. (2019). Factors affecting disclosure of environmental accounting information in Vietnamese aquaculture enterprises. Ho Chi Minh City, Vietnam: Doctoral dissertation, University of Economics.

Liu, X., \& Anbumozhi, V. (2009). Determinant factors of corporate environmental information disclosure: an empirical study of Chinese listed companies. Journal of Cleaner Production, 17(6), 593-600. https://doi.org/10.1016/j.jclepro.2008.10.001

Lu, Y., \& Abeysekera, I. (2014). Stakeholders' power, corporate characteristics, and social and environmental disclosure: evidence from China. Journal of Cleaner Production, 64, 426436. https://doi.org/10.1016/j.jclepro.2013.10.005

Megbuluba, A. (2017). The Level Corporate Environmental Accounting Information Disclosure in the Manufacturing Sector in Nigeria; a Voluntary Perspective. Available at SSRN: http://dx.doi.org/10.2139/ssrn.3003996

Ministry of Construction (2018). Circular No. 02/2018/TT-BXD on providing for Environmental Protection in Construction And Reporting Thereof. Retrieved May 06, 2018, from http:// congbao.chinhphu.vn/noi-dung-van-ban-so-02-2018-tt-bxd25910 ?cbid $=21426$

Ministry of Construction (2018). Decision No. 1659/QD-BXD on promoting the action plan of the construction industry by implementing the national action plan to implement the 2030 agenda for sustainable development. Retrieved May 05, 2018, from http://moc.gov.vn/vn/Pages/ChiTietVanBan. aspx?vID $=270 \&$ TypeVB $=0$

Ministry of Finance (2015). Circular 155/2015/TT-BTC on guiding information disclosure on the stock market. Retrieved May 06, 2018, from http://vbpl.vn/botaichinh/Pages/ vbpq-van-bangoc.aspx?ItemID=91233.

Nguyen, L. S., Tran, M. D., Nguyen, T. X. H., \& Le, Q. H. (2017). Factors Affecting Disclosure Levels of Environmental Accounting Information: The Case of Vietnam. Accounting and
Finance Research, 6(4), 255-264. https://doi.org/10.5430/afr. v6n4p255

Nguyen, L.S., Tran, T.H. \& Nguyen, T.N. (2018). Factors Affecting Disclosure Level of Environmental Accounting Information The Case of Vietnamese Firms Doing Business under the Model Parent Company - Subsidiary Company. Paper read at The 5th IBSM International Conference on Business, Management and Accounting (pp. 710-723). Hanoi, Vietnam, April 19-21.

Nguyen, T. M. H., Le, P. M. L., \& Pham, K. L. (2018). Factors Affecting Disclosure Levels of Environmental Accounting Information: The case of food processing companies listed at Ho Chi Minh Stock Exchange. Industry and Trade Magazine, 2, 318-330. Retrieved from http://www.tapchicongthuong.vn/

Nguyen, T. L. H., Nguyen, T. T. H., Nguyen, T. T. H., Le, T. H. A., \& Nguyen, V. C. (2020). The Determinants of Environmental Information Disclosure in Vietnam Listed Companies. Journal of Asian Finance, Economics and Business, 7(2), 21-31. https:// doi.org/10.13106/jafeb.2020.vol7.no2.21

Nguyen, T. K. T. (2020). Studying Factors Affecting Environmental Accounting Implementation in Mining Enterprises in Vietnam. Journal of Asian Finance, Economics, and Business, 7(5), 131-144. https://doi.org/10.13106/jafeb.2020. vol7.no5.131

Peskin, H. M., \& Angeles, M. S. D. (2001). Accounting for environmental services: contrasting the SEEA and the ENRAP approaches. Review of Income and Wealth, 47(2), 203-219. https://doi.org/10.1111/1475-4991.00012

Saifullah, M. K., Kari, F. B., \& Ali, M. A. (2017). Linkage between public policy, green technology and green products on environmental awareness in the urban Kuala Lumpur, Malaysia. Journal of Asian Finance, Economics and Business, 4(2), 4553. http://dx.doi.org/10.13106/jafeb.2017. vol4.no2.45

Solomon, J. F., \& Thomson, I. (2009). Satanic Mills?: An illustration of Victorian external environmental accounting. Accounting Forum, 33(1), 74-87. https://doi.org/10.1016/j. accfor.2008.07.012

Steele, A. P., \& Powell, J. R. (2002). Environmental Accounting: Applications for Local Authorities to Quantify Internal and External Costs of Alternative Waste Management Strategies. Environmental Management Accounting Network Europe, Fifth Annual Conference (pp. 12). Cheltenham, UK, February 11-12. Cheltenham, UK: Gloucestershire Business School.

The Prime Minister of Government (2012). Decision No. 1393/QDTTg on approving the National Strategy on Green Growth in The Period of 2011-2020 and Vision to 2050. Retrieved May, 06, 2018, from http://vanban.chinhphu.vn/portal/page/portal/ chinhphu/hethongvanban?_page=1\&class_id=2\&document id $=163886 \&$ mode $=$ detail

The Prime Minister of Government (2018). Decision No. 950/QDTTg on approving scheme for development of smart sustainable cities in Vietnam in the 2018 - 2025 period with orientations by 2030. Retrieved May, 06, 2018, from http://vanban.chinhphu. vn/portal/page/portal/chinhphu/hethongvanban?class_id=2\&_ page $=1 \&$ mode $=$ detail\&document_id=194337 
Wachira, M. M. (2014). Factor influencing the adoption of environmental management accounting practices among firms in Nairobi, Kenya. Nairobi, Kenya: Doctoral dissertation, University of Nairobi.

Wijewardana, W.P. (2017). The Adoption of Environmental Management Accounting Practices Among Manufacturing Companies In Sri Lanka. Global Scientific Journals, 5(11), 95104.

Wooldridge, J. (2002). Econometric Analysis of Cross Section and Panel Data. Cambridge, MA: The MIT Press.
Yakhou, M., \& Dorweiler, V. P. (2004). Environmental accounting: an essential component of business strategy. Business Strategy and the Environment, 13(2), 65-77. https://doi.org/10.1002/ bse. 395

Yang, L. H., \& Liang, X. T. (2017). Study on the Influencing Factors of Environmental Accounting Information Disclosure. International Conference on Economics, Management Engineering and Marketing (EMEM 2017) (pp. 134-141). 